\title{
HELP FOR THE SICK DOCTOR
}

The Association of Anaesthetists of Great Britain and Ireland and the Royal College of Psychiatrists are co-operating in a pilot venture to bring help to sick anaesthetists early in their illness. The proposed system would depend upon voluntary reporting by colleagues and is non-coercive. It must be emphasized that this scheme is supplementary to existing controls. Fitness to practise may be impaired through illness and the sick doctor for various reasons does not take any steps to remedy the situation. This scheme provides machinery whereby confidential psychiatric help can be offered to the ailing doctor from a source outside his own Area or Region. If successful, the scheme could be extended to other branches of the medical profession.

The reporting clinician contacts the Association of Anaesthetists' office to learn the name of a referee ( $\mathrm{Dr}$ A. J. Beard, Professor A. C. Forrester, Dr P. J. Helliwell, Dr J. Alfred Lee, Professor W. W. Mushin, Professor Sir Robert MacIntosh, Professor Sir Geoffrey Organe) and need not identify himself to the office staff. The reporting clinician will be given the name, telephone number and availability of the referee. Preferably, a second clinician will also be required to confirm the report to the referee. The referee then contacts a psychiatrist from another Region nominated by the Royal College of Psychiatrists from a prepared list: the psychiatrist then contacts the potential patient. No further information will be transmitted through the system unless the potential patient does not accept the offer of a visit to the nominated psychiatrist. In that case, the reporting physician(s) will be informed after a month that treatment has not been accepted. Suitable arrangements have been made for confidential treatment of the doctor-patient in another Region and for reimbursement of travel expenses. In this connection the Medical Defence Union has made a generous donation.

The scheme can be initiated confidentially through the Association of Anaesthetists of Great Britain and Ireland, Room 475/478, Tavistock House South, Tavistock Square, London WC1H 9LG. (Telephone: 01387 4782).

K. RAWNSLEY Chairman, College Committee on Sick Doctors.

\section{FORTHCOMING EVENTS}

MRC Psych. Basic Science Course, Charing Cross Hospital

Term I runs from 8 May-17 July 1979. Term fee $£ 80$; registration fee $€ 15$. Details from Secretary to $\mathrm{Dr}$ Weller, Department of Psychiatry, Charing Cross Hospital, Fulham Palace Road, London, W6 8RF.

Third South-East European Neuropsychiatric Conference

The Third South-East Neuropsychiatric Conference will be held in Thessaloniki, Greece, from 26-29 September. The main topic will be 'Neurological and Psychiatric Problems in General Medicine'. Further information from Asst Prof E. C. Dimitriou, General Secretary, South-East European Society for Neurology and Psychiatry, 80 Mitropoleos Street, Thessaloniki.

First International Conference on Stress and Tension Control

The First International Inter-disciplinary Conference on Stress and Tension Control, jointly organized by the American Association for the Advancement of Tension Control and the West London Institute of Higher Education, will be held in London from 10-14 September. Papers on the application of techniques of stress and tension control in behaviour modification are invited. Further information from J. Macdonald Wallace, Principal Lecturer in Health Education, West London Institute for Higher Education, Lancaster House, Borough Road, Isleworth, Middlesex.

\section{European Union of Child Psychiatrists}

The Sixth Congress of the European Union of Child Psychiatrists will be held in Madrid from 25-29 June. Further information from the Secretariat, TILESA, Londres 41, Madrid-28, Spain.

\section{Third S. H. Foulkes Lecture}

This lecture, on 21 May at the Royal College of Physicians, at 8.30 p.m. (see April Bulletin) will now be given by Professor Wilfred Abse, Professor of Psychiatry of the University of Charlottesville, U.S.A., on. 'The Complementary Function of Group Analysis and Psycho-Analysis'.

Institute of Family Therapy (London)

A Clinical Workshop in Family Therapy, intended for those who have attended an Introductory Course and have had some clinical experience in Family Therapy, will be held on Wednesday mornings for 20 sessions, beginning on 10 October. Further details and application forms from: The Course Secretary, Institute of Family Therapy (London), 5 Tavistock Place, London, W.C.1. Telephone: 01-388 3872. 